and of the nominating committee. These alterations make the organisation more like that of the British Association for the Advancement of Science, and became necessary on account of the recent rapid growth of the Association. The membership has doubled within two years, being now about I 800 .

The recommendation of the Standing Committee to meet in 1882 at Montreal was adopted with acclamation. The invitation from Minneapolis for I883 was referred to the Standing Committee.

The Association elected Dr. J. W. Dawson of Montreal President for the ensuing year. The time of meeting was fixed for the fourth Wednesday in August, 1882, Nearly seventy Fellows were elected by ballot, and the following officers for 1882 , in accordance with the recommendation of the Nominating Committee, were unanimously elected :-

Officers for 1882. Vice-presidents: Section A, Mathematics and Astronomy, Prof. William Harkness, U.S.N.; Section B, Physics, Prof. T. C. Mendenhall of Columbus; Section C, Chemistry, Prof. H. Carrington Bolton, Ph.D., of Hartford, Conn.; Section D, Mechanical Science, Prof. W. P. Trowbridge, Ph.D., of Columbia College, New York; Section E, Geology, Prof. E. T. Cox of San Francisco; Section F, Biology, Capt. W. H. Dall of Washington, D.C. ; Section G, Histology and Microscopy, Prof. A. H. Tuttle of Columbus, Ohio ; Section $\mathrm{H}$, Anthropology, Prof. Daniel Wilson of Toronto; Section I, Economic Science and Statistics, E. B. Elliot of Washington, D.C.

We have already (vol. xxiv. p. 455) referred to the action taken by the Association in reference to science degrees.

The following are some of the principal papers read at the meeting :-

In Section A : Magnetic survey of Missouri, by Prof. F. E. Nipher; on the methods of determining the solar parallax with special reference to the coming transit of Venus, by Prof. William Harkness; on the wave-lengths of the principal lines of the solar spectrum, by Prof. T. C. Mendenhall ; experiments to determine the comparative strength of globes and cylinders of the same diameter and thickness of sides, by Samuel Marsden historic notes on cosmic physiology, by Dr. T. Sterry Hunt; upon the use of the induction balance as a means of determining the location of leaden bullets imbedded in the human body, by Prof. Alex. Graham Bell; upon a new form of electric probe, by the same; on a new method of applying water-power of small head to effect the direct compression of air to any required high pres sure, by Prof. H. T. Eddy; the needle telephone, a new instrament by Dr. Goodman of Louisville, Ky., by Dr. J. Lawrence Smith; an improved sonometer, by W. Le Conte Stevens; on the great outburst in comet $b$, I $88 \mathrm{r}$, observed at the Cincinnati Observatory, by Prof. Ormond Stone; method of determining the value of the solar parallax from meridian observations of Mars, by Prof. J. R. Eastman; numbers of cometary orbits relative to perihelion distance, by Prof. H. A. Newton; numerical elements of the orbits of the seven electrical vortices to whose motions atmospheric storms are principally due, with the processes by which they have been derived, and examples given of the application of the formula by which their positions on the surface of the earth can be computed for any given time, by Thomas Bassnett; a preliminary investigation of the two causes of lateral deviation of spherical projectiles, based on the kinetic theory of gases, by Prof. H. T. Eddy; note on the theory of the flight of elongated projectiles, by Prof. H. T. Eddy; on the mechanical principles involved in the flight of the boomerang, by Prof. H. T. Eddy; the electrophore and electric lighting, by Mr. E. B. Elliott ; nodular concretions in meteoric iron, bearing on the origin of same, by Dr. J. Lawrence Smith ; an anomalous magnetic property of a specimen of iron, by Dr. J. Lawrence Smith; on the errors to which self-registering clinical thermometers are liable, by Dr. Leonard Waldo; a new radiometer, by Dr. H. Carmichael; a new differential thermometer, by Dr. H. Carmichael; note on an experimental determination of the value of $\pi$, by Prof. T. C Mendenhall; remarks upon, and an exhibition of, Japanese magic mirrors, by the same; on standard time, by $E$. $B$.
Elliott; note on a comparison of Newcomb's tables of Uranus and Neptune, with those of the same planets by Leverrier, by D. P. Todd ; universal energy of light, by Pliny Earle Chase electricity, magnetism, gravitation-their phenomena considered as the manifestations of one force, by S. S. Parsons.

In Section B : On the influence of the structure of the nervefibres upon the production and conduction of nerve-force, by H. D. Schmidt; on the action of pilocarpin in changing the colour of the human hair, by Dr. D. W. Prentiss; the unification of geological nomenclature, by Dr. R. Owen; the life-unit in plants, by Prof. B. D. Halsted; recent discoveries, measurements, and temperature observations made in Mammoth Cave, Ky., by Rev. H. C. Hovey ; influence of forests upon streams, by David D. Thompson; note on the segmentation of the vertebrate body, by Charles Sedgwick Minot; phenomena of grow th in plants, by D. P. Penhallow; the recurrence of faunas in the Devonian rocks of New York, by H. S. Williams; a contribution to Croll's theory of secular climatal changes, by W. J. McGee; the evidence from the drift of Ohio in regard to the origin of Lake Erie, by E. W. Claypole; on some relations of birds and insects, by S. A. Forbes ; Niagara River, its cañon, depth, and wear, by Wm. Hosea Ballou; evolution and its place in geology, by Edward S. Edmunds.

In Section C : Is the law of repetition the dynamic law underlying the science of chemistry? by Miss V. K. Bowers; evidences of atomic motion within molecules in liquids, as based upon the speed of chemical action, by Prof. R. B. Warder ; the con titu. tion of the "atom" of science, by Mrs. A. B. Blackwell; the sources of nitrogen in plants, by Prof. W. O. Atwater; notes in experimental chemistry, by Prof. A. B. Prescott ; determination of phosphorus in iron, by Dr. J. Lawrence Smith; the liquefaction of glass in contact with water at $250^{\circ} \mathrm{C}$., by Prof. H. Carmichael ; the chemistry of fish and invertebrates, by Prof. W. $O$. Atwater; notes in experimental chemistry, by Prof. Albert B. Prescott; the quantitative estination of nitrogen, by Prof. W. O. Atwater ; the quantitative estimation of chlorine, by Prof. W. O. Atwater; the nitrogenous constituents of grasses, by Clifford Richardson.

In Section D (Anthropology): Animal myths of the Iroquois, by Mrs. Erminnie A. Smith; antiquity of man in America, by W. de Haas; progress of archæological research, by W. de Haas; the mound builders : an inquiry into their assumed southern origin, by W. de Haas.

In Section E (Microscopy): On a convenient method of expressing micrometrically the relation between English and metric units of length on the same scale, by William A. Rogers and George F. Ballou.

In Section F (Entomology); On the length of life of butterflies, by Prof. W. H. Edwards; on the life duration of the Heterocera (moths), by Prof. J. A. Lintner; how does the bee extend its tonoue? by A. J. Cook; the egg-sase of Hydrophilus triangularis, by Dr. C. V. Riley; on the oviposition of Prodoxus decipiens, by the same; the cocoon of Gyrinus, by the same ; suggestions of co-operation in furthering the study of entumology, by Prof. B. P. Mann.

\section{THE BRITISH ASSOCIATION \\ REPORTS}

Report of the Committee on Tidal Observations in the Enolish Channel and the North Sea, by J. N. Shoolbred.-In the report it was stated that no official reply had been received by the Committee as to having an international datum for observations, or as to maritime governments giving facilities for detailed observations. The Committee urged the desirability of carrying out a series of observations on the Azores. The Portuguese Government had established a station for registering tides, as had also our own Government at Dover. The Committee hoped before long to have a series of observations giving most important results.

Report of the Committee for Underground Temperature, by Prof Everett. - In the report it was stated that the temperatuie varied from one degree for 30 feet to une degree for 100 feet in going down beneath the surface of the earth in different places. During the past year observations have been made in the East Manchester coal field, the Talavgoch lead mine, Flintshire, and at the Radstock collieries, Bath. With regard to the observations in the East Manchester coal-field, these were respectively 
taken at Ashton Moss, Bredbury, and Nook Pit : the temperatures were as follows:-
Place.
Ashton Mo:s
Depth.
Feet.
Feet.
Bredbury Colliery

$\begin{array}{ccccc} & & & & \begin{array}{c}\text { Depth. } \\ \text { Feet. }\end{array} \\ \ldots & \ldots & \ldots & 2790 \\ \ldots & \ldots & \ldots & \text { 1020 } \\ \ldots & \ldots & \ldots & \text { 1050 }\end{array}$
Temperature. $85^{\circ} 3$

The increments of temperature would be as follows :-

$\begin{array}{cc}\text { Place. } & \text { Depth. } \\ \text { Feet. } & \text { Increase of } \\ \text { temperature. }\end{array}$

$\begin{array}{llllllll}\text { Ashton Moss } \ldots & \ldots & \ldots & \ldots & 2790 & \ldots & \ldots & 3^{\circ} \cdot 3 \\ \text { Bredbury Colliery } & \ldots & \ldots & \ldots & 1020 & \ldots & \ldots & 13 \\ \text { Nod } & \ldots & \ldots & \end{array}$

$\begin{array}{lllllllllll}\text { Nook Pit } & \ldots & \ldots & \ldots & \ldots & \ldots & 1050 & \ldots & \ldots & 13.3\end{array}$

This gave for each degree of increase, Ashton Moss $76^{\circ} 9$ feet, Bredbury 78.5 , and Nook Pit, 79 feet. In Flintshire the observations showed great irregularity last year, and the observations taken this year increased the irregularity. The observations were taken at a place in the lead mine at a depth of 660 feet ; at this depth the temperature was $62^{\circ}, 48^{\circ}$ being assumed to be the surface temperature which gave an increase of $14^{\circ}$ in 660 feet, or $\mathrm{I}^{\circ}$ in 47 feet. At the Radstock colliery observations were made at three places. The Wells May Pit, 560 feet deep, the Ludlow Pit, rooo feet, and a third station in the same pit 810 feet deep, the surface temperature being assumed $50^{\circ}$, the rate of increase was found to be $11^{\circ} 7$ in 560 feet, and $13^{\circ}$ for both 810 feet and rooo feet.

Mr. W. M. Hicks read his report On Recent Progress in Hydrodynamics, which he related to the investigations undertaken since 1846, the date of Prof. Stokes's well-known report.

A Report of the Committee on Fundamental Invariants, by Prof. Sylvester, was read.

Report of Committee on Mathmatical Tables, by James Glaisher, F.R.S.-The author stated that the factor table for the sixth million was now completed and sterestyped, and he had the pleasure to exhisit to the section proofs of the whole of this million taken from the stereotyped plates. The factor tables fo: the fourth and fifth millions had been already published, so that now the gap of three millions between the iables of Burckhardt (1817) and those of Dase (186r) was completely filled up. The introduction to the sixth million would shortly be completed, when this volume would appear.

Report on the Tertiary Flora of the Basalt of the North of Ireland, drawn up and illustrated by W. H. Bailey, Geological Survey of Ireland.

Mr. Sclater, in the absence of Mr. Thiselton Dyer, presented the Report of the Committee appointed for the Purpose of Investigating the Natural History of Timor-lant. - In a letter addressed to Sir Joseph Hooker, director of the Royal Gardens, Kew, Mr. H. O. Forbes had written from Sumatra, offering, if some assistance could be forwarded to him, to attempt an expedition to Timor-lant, for the purpose of investigating its natural history - "an object," as Mr. Forbes statel, "the accomplishment of which is de ired both by botanists and $z$ jologi ts." An appli. cation on Mr. Forbes's behalf was accordingly made to the British Association, and a sum of $50 \%$ was voted by the General Committee at the Swansea Mecting to be placed at the disposal of the Committee, to whom the conduct of the matter was intrusted. The action taken by the Association was communicated to Mr. Forbes, and a letter was received in reply. This was the most recent information which the Committee possessed as to his plan:. It was somewhat doubtful whether, owing to insufficiency of funds, he was able to start. At any rate, the grant made at Swansea remained in the hands of the Committee. The expedition was obviously attended with some difficulty, if not danger. Its success must be largely dependent on fortunate accident. The Committee, however, thought that there was a reasonable chance of the work being done, and therefore recommended their reappointment, and that a further sum of $\mathbf{1 0 0}$. be placed at their disposal.

The Report of the Committee on the Natural History of Socotra gave an account of the progress made in working out Prof Bayley Balfour's collections, and recommended its reappointment with a somewhat extended sf here, so as to embrace the adjoining highlands of Arabia and Somali Land.

A Report by Mr. R. J. Us her On Caves and Kitchen-Middens at Cappagh, County Waterford, de sribed an extensive series of kitehen-middens which had been excavated with the aid of the
Association grant. Oae of these filled a cave of considerable extent, the more ancient parts of which had not been yet ex. plored. The excavated parts yielded large quantities of bones and implements which did not furnish very striking results.

The Report of the Committee for the Investigation of the Influence of Bodily Exercise on the Elimination of Nitrogen, presented by Mr. North, detailed the delays in commencing the actual investigation, owing to the necessary devising and construction of instruments. It was hoped however that valuable results might be obtained before the meeting at Southampton.

The Report of the Committee on the Zoological Station at Naples was read by Mr. Percy Sladen. He stated that the laboratory had added micro-spectroscopic and polariscopic apparatus, a new Du Bois-Reymond's section apparatus, and a valuable series of chemico-physiological apparatus; and the breeding and aërating apparatus have been successfully worked. Two of the monographs of the Fauna and Flora of the Gulf of Naples have been published in the last year, viz., the Ctenophora by Dr. Carl Chun, and the species of the genus Fierasfer by Dr. Carlo Emery. The monographs on the Pantopoda, by Dr. Dohrn. the Corallines, by Solins-Laubach ; and on Balanoglossus, by Dr. J. W. Spengel, are in a forward state. The Zoologische Fahresberichte for 1880 is in the press, and will be issued in four parts. The novel method of investigating the sea-bottom by means of diving apparatus has been successfully used in many clear portions of the bed near Naples. Many details of improvement have been made, and many fissures and cavities may be explored which are inaccessible to the trawl or the dredge, and sponges, hydroids, actinix, bryozoa and planarians, nudibranchs and algæ may be obtained in situ. During the year Mr. Allen Harker has studied at the British Association table, chiefly on the circulation and respiration in the polychætons annelids; also Mr. F. G. Penrose, who i ivestigated the circulation ia Solen legumen. Mr. P. Geddes desires to prosecute special researches during the coming year, and will be accompanied by an assistant. Thirty-four naturalists have worked at the station during the year, many memoirs have been published, large quantities of specimens have been sent to foreign museums and naturalists, as well as micro copical preparations.

Report of the Committee, consisting of Mr. Fames Heywood, F.R.S., Mr. William Shaen, Mr. Stephen Bourne, Mr. Robert Wilkinson, the Rev. W. Delany, Mr. N. Story Maskelyne, M.P., F.R.S., Dr. Silvanus P. Thompson, Miss Lydia E. Becker, Sir Fohn Lubbock, Bart., M P., F.R.S., Prof. A. W. Williamson F.R.S., Mrs. Augusta Webster, and Dr. T. H. Gladstone, F.R.S. (Secretary), on the manner in which Rudimentary Science should be taught, and how Examinations should be held therein, in Elementary Schools. - Rudimentary science is taught in public elementary schools in the form of-I. Object lessons ; II. Class subjects under article I9, c. I, of the New Code; III. Specific subjects under Schedule IV. of the same Code; IV. Science subjects preparatory to entering classes in connection with science schosls.

I. Object lessons are attemptel in a large number of infant schools, and in some instances are very effective in developing the perceptive powers and intelligence of the children; but in other case they are too formal, and left too much to the junior teacher:. In b sys' and girls' schosls they frequently appear upon the time table, especially where, as in the schools of the London B ard, they are looked upon as a necessary part of the instruction: but they are generally given in an unsystematic, and often in an unsati:factory manner.

II. The teaching of science as a class subject under the Code only commenced last October, and thus no examinations have yet been held under it. Natu al history, physical geography, natural philosophy, \&c., are mentioned in article 19, c. I, and it is stated that the instruction should be given "through reading lessons, illu trated, if necessary, by maps, diagrams, specimens, \&c."; but the teachers are limited to two subjects, and the old subjects, grammar, history, geography, and needlework naturally retain their place in the grear majority of the schools. Suitable reading-books for these rudimentary science subjects have scarcely yet came into existence.

III. The specific subjects of the fourth schedule include mechanics, animal physiology, physical geography, botany, and domestic economy, but only two subjects may be taken (or three if the child has passed Staudard VI.); and the schedule also includes English literature, mathematics, Latin, French, and German. Literature is a general favourite; and domestic 
economy is obligatory in girls' schools if any specific subject is taken at all ; Si) that the chance of any of the others being introduced is very much diminished. It must also be rememiered that these subjects are only allowed to be taught to children in the Fourth Standard and upwards; while only about one-fifth of the children in the boys' and girls' schools are to be found at present in these standards. According to the Report of the Committee of Council for Education recently issued, there were $476,76 \mathrm{I}$ children presented for examination in these standards, of whom the following numbers only were examined in the science subjects :-

$\begin{array}{lllllr}\text { Mechanics _.. } & \ldots & \ldots & \ldots & \ldots & 2,109 \\ \text { Animal physiology } & \ldots & \ldots & \ldots & \ldots & 24,725 \\ \text { Physical geography } & \ldots & \ldots & \ldots & \ldots & 34,288 \\ \text { Botany ... } \ldots & \ldots & \ldots & \ldots & \ldots & 1,853 \\ \text { Domestic economy } & \ldots & \ldots & \ldots & \ldots & 50,797\end{array}$

Out of 489 boys' and girls' departments under the London School Board, the specific science subjects were taken up, as follows, during the year I880:-

\begin{tabular}{|c|c|c|c|c|}
\hline Mechanics in ... & & & \multicolumn{2}{|c|}{4 departments } \\
\hline A tuimal physiology in & $\ldots$ & $\ldots$ & 123 & , \\
\hline Physical geography in & $\ldots$ & $\ldots$ & II 2 & ", \\
\hline Botany in $\quad \ldots \quad \ldots$ & $\ldots$ & $\ldots$ & 9 & ", \\
\hline Domestic econo: & $\ldots$ & $\ldots$ & I 72 & ", \\
\hline
\end{tabular}

Mr. Hance of the Liverpool School Board has favoured us with an account of the systematic scientific instruction which is given in the Board schools of that town by a special science staff. The subject selected for the boys is mechanics as defined in the New Code, with a considerable development in the direction of elementary physics. It has been in operation since 1877 , and the results for the year $1880-8 \mathrm{I}$ are given in the following table :-

\begin{tabular}{|c|c|c|c|c|c|c|}
\hline \multirow{2}{*}{$\begin{array}{c}\text { Year } \\
\text { r88o-8r. } \\
\text { Stage I. }\end{array}$} & \multicolumn{2}{|c|}{$\begin{array}{c}\text { Number } \\
\text { presented. }\end{array}$} & \multicolumn{3}{|c|}{$\begin{array}{l}\text { Number } \\
\text { passed. }\end{array}$} & \multirow{2}{*}{$\begin{array}{c}\text { Percentage } \\
\text { of passes. } \\
55^{\circ} 46\end{array}$} \\
\hline & $\ldots$ & 797 & $\ldots$ & 442 & & \\
\hline,,$\quad$ II. ... & $\ldots$ & 398 & $\ldots$ & $26 \mathrm{I}$ & $\ldots$ & $65 \cdot 59$ \\
\hline III.. & $\ldots$ & 122 & $\ldots$ & 82 & $\ldots$ & $67.2 x$ \\
\hline &.. & 317 & $\ldots$ & 785 & & 59 \\
\hline
\end{tabular}

Domestic economy is also taught to the girls in a similar manner. In Birmingham I 200 scholars are receiving scientific instruction in the schools of the Board, and it is stated that the teachers uniformly find that "it added interest to the work of the school, that the children were eager to be present, and that the lesson. were enjoyed, and were in fact giving new life to the schools." The Board have found the results so satisfactory that they are now furnishing their newest school with a laboratory and lecture room.

IV. As to science-teaching which does not fall under the provisions of the New Code it is not probable that any large amount is attempted. In Manchester, however, the Board gives instruction to 404 children, all of whom have passed Standard VI., the highest ordinary standard, in the following subjects : physiology acoustics, light, and heat; magnetism and electricity; chemistry ; practical chemistry ; botany. This teaching is illustrated by means of good apparatus, \&c., and has had a very beneficial effect upon the science and art classes of the town. When it is considered that the provisions of the Code naturally form, in almost all cases, the extreme limit of what will be attempted in the schools, it is important that they should be placed as high as possible. This will be a great advantage to the stronger schools, and no disadvantage to the weaker ones, as the higher branches of science-teaching will of course be optional. Your committee have, therefore, arrived at the following conclusions:-

I. As to object lessons. That it is very desirable that Her Majesty's Inspectors should take object lessons into account in estimating the teaching given in an infant school; and that they should examine the classes in the graded schools wherever object lessons are given.

II. As to class subjects. That the teaching of such subjects as natural history, physical geography, natural philosophy, \&c. should not necessarily be "through reading lessons," as oral lessons, "illustrated by maps, diagrams, specimens, \&c.," are undoubtedly better when given by a teacher duly qualified to handle these subjects. They are of opinion, also, that it will be desirable to allow a larger number of class subjects to be taken up in any particular school, and to give in such ca:e a proportionately increased grant.

III. As to specific science subiects. That a knowledge of the facts of nature is an essential part of the education of every child, and that it should be given continuously during the whole of school life from the baby class to the highest standard. Of course in early years this teaching will be very rudimentary; but by developing the child's powers of perception and comparison it will prepare it for a gradual extension of such knowledge. They consider also that the early teaching must be very general, while the later may be more specific ; they think, however, that the science subjects as given in Schedule IV, are fairly open to objection, as being somewhat too ambitious in their nomenclature and in their scope, and that they ought not to be attempted unless the child has had a previous training in natural knowledge before entering the fourth standard. Thus the specific scientific subjects ought not to be distinct, as they practically are at present, from the previous teaching; greater latitude of choice might be allowed in them; and while they should not afford technical instruction they should prepare the way for any technical classes or schools into which the children may subsequently enter. In regard to domestic economy they are of opinion that most of the points embraced in the schedule would be useful to boys as well as to girls.

1V. As to examinations. That in the appointment of Her Majesty's Inspectors some knowledge of natural science should be considered as absolutely requisite; that in examining the children they should direct their inquiries so as to elicit not so much their knowledge of special facts as their intelligent acquaintance with the world of nature around them; and that this.may be much better done by oral examination than by paper work.

\section{SECTION A-Mathematical and Physical}

On the Economy of Metal in Conduclors of Electricity, by Sir W. Thomson,-The most economical size of the copper conductor for the electric transmission of energy, whether for the electric light or for the performance of mechanical work, would be fourd by comparing the anuual interest of the money value of the cspper with the money value of the energy lost in it annually in the heat generated in it by the electric current. The money value of a stated amount of energy had not yet begun to appear in the City price lists. If $\mathbf{I} 0$. were taken as the par value of a horse-power night and day for a year, and allowing for the actual value being greater or less (it might be very much greater or very much less) according to circunstances, it was easy to estimate the right quantity of metal to be put into the conductor to convey a current of any stated strength, such as the ordinary strength of current for the powerful arc light, or the ten-fold strength current (of 240 webers) which he (Sir William Thomson) had referred to in his address as practically suitable for delivering 21,000 horse-power of Niagara at 300 miles from the fall. He remarked that (contrary to a very prevalent impression and belief) the gange to be chosen for the conductor does not depend on the length of it thruugh which the energy is to be transmitted. It depends solely on the strength of the current to be used, supposing the cost of the metal and of a unit of energy to be determined. Let $A$ be the sectional area of the conductor; $s$ the specific resistance (according to bulk) of the metal; and $c$ the strength of the current to be used. The energy converted into heat and so lost, per second per centimetre, is $s c^{2} / A$ ergs. Let $p$ be the proportion of the whole time during which, in the course of a year, this current is kept flowing. There being $3 \mathbf{I} \frac{1}{2}$ million seconds in a year, the loss of energy per annum is $3 \mathrm{I} \cdot 5 \times 10^{6} p s c^{2} / A$ ergs

The cost of thi, if $E$ be the cost of an erg, is

$$
3 \mathrm{I}^{\circ} 5 \times 10^{6} p s c^{2} E / A
$$

Let $V$ be the money value of the metal per cubic centimetre. The cost of possessing it, per centimetre of length of the wire, at 5 per cent. per annum, is

$$
V A / 20
$$

Hence the whole annual cost, by interest on the value of the metal, and by loss of enersy in it, is

$$
\frac{\mathrm{I}}{20} V A+\frac{3 \mathrm{I} \cdot 5 \times 10^{6} p s c^{2} E}{A} \text {. }
$$

The amount of $A$ to make this a minimum (which is also that which makes the two constituents of the loss equal) is as follows :-

$$
\begin{aligned}
A= & \sqrt{ }\left(3 \mathrm{I} \cdot 5 \cdot 10^{6} p s c^{2} E / \frac{V}{20}\right) \\
& =c \sqrt{ }\left(63 \cdot 10^{7} p s E / V\right) .
\end{aligned}
$$

